\title{
Cost and price auditing: effectiveness in the procurement of defense services in Spain
}

\author{
José Aguado Romero \\ Universidad de Granada (UGR) / Facultad de Educación, Economía y Tecnología \\ Ceuta - Spain \\ Antonio M. López Hernández \\ Cámara de Cuentas de Andalucía \\ Sevilla - Spain
}

\begin{abstract}
Contract auditing, or cost and price auditing, has been applied in Spain as a means of determining prices in non-competitive defense contracts since 1989. Factors such as Spain's participation in international defense organizations, the characteristics of the defense market and the contractual legal framework for the procurement of defense goods and services help underscore the need for the Spanish Ministry of Defense to implement cost and price auditing. With the evolution of cost and price auditing in Spain in mind, this paper analyses the entire process, describes the audit procedures that are most commonly used today and assesses the main results achieved, in terms of financial savings. The results obtained show that cost and price auditing does indeed contribute to a more efficient use of public resources.
\end{abstract}

KEYwords: defense acquisitions; contract auditing; non-competitive contracts; Ministry of Defense; Spain.

A auditoria de custos e preços: eficácia nos serviços contratantes de defesa na Espanha A auditoria de contratos, ou auditoria de custos e preços, aplica-se na Espanha como uma ferramenta para a fixação dos preços dos contratos de defesa não competitivos desde 1989. A participação da Espanha em organismos internacionais de defesa, as características do mercado de defesa e o quadro normativo contratual em que se realizam as aquisições de bens e serviços para a defesa têm propiciado a necessidade da implementação da auditoria de custos e preços por parte do Departamento de Defesa da Espanha. Tendo em conta a evolução que sua aplicação tem tido na Espanha, os objetivos deste artigo são: analisar no seu conjunto o processo da auditoria de custos e preços e as modalidades de auditoria mais usadas atualmente, assim como os principais resultados alcançados em termos de

DOI: http://dx.doi.org/10.1590/0034-7612152005

(c) (i)

Article submitted on Jul. 14th, 2015 and accepted for publication on Jun. 16th, 2016. 
poupanças monetárias. Os resultados obtidos mostram que a auditoria de custos e preços contribui para um uso mais eficiente dos recursos públicos.

Palavras-chave: aquisições de defesa; auditoria de contratos; contratos não competitivos; Ministério da Defesa; Espanha.

La auditoría de costes y precios: eficacia en los servicios de contratación de defensa en España La auditoría de contratos o auditoría de costes y precios se aplica en España como herramienta para la fijación de los precios de los contratos de defensa no competitivos desde 1989. La participación de España en organismos internacionales de defensa, las características del mercado de defensa y el marco normativo contractual en el que se realizan las adquisiciones de bienes y servicios para la defensa han propiciado la necesidad de la implantación de la auditoria de costes y precios por parte del Departamento de Defensa de España. Teniendo en cuenta la evolución que su aplicación ha tenido en España, los objetivos de este artículo son: analizar en su conjunto el proceso de la auditoria de costes y precios y las modalidades de auditoría más utilizadas en la actualidad, así como los principales resultados alcanzados en términos de ahorros monetarios. Los resultados obtenidos muestran que la auditoría de costes y precios contribuye a un uso más eficiente de los recursos públicos.

Palabras clave: adquisiciones de defensa; auditoria de contratos; contratos no competitivos; Ministerio de Defensa; España.

\section{Introduction}

In general, in the procurement of goods and services, public authorities publicise the process and invite suppliers to present tenders, or bids (Barea and Gómez, 1994), while market mechanisms determine the price, which should be regarded as fair or reasonable by all parties.

However, in certain sectors, such as national defence, the market for goods and services is not perfectly competitive, due to product constraints or reasons of security. It is sometimes considered a captive market, subject to the political and budgetary constraints of each state (Álvarez and Fonfría, 2000) and to the obvious fact that a very limited number of firms are present in the defence industry. In short, the public procurement of weapons and weapons systems often takes place in a non-competitive environment, within an imperfect market (McGuire, 2007).

In view of the characteristics of the defence market and the need for constant adaptation to the changing needs of public administrations, changes are taking place in traditional structures and management systems for procurement. In most countries with long experience in defence spending on weapons and other military equipment, the following adaptations in procurement procedures have taken place: the adjustment of award procedures in the case of non-competitive contracts; the regulatory development of the general framework for the application of these procedures in the defence sector; the stipulation of rules enabling the application of cost controls in this type of contract; the creation of specific bodies to review 
costs and prices; and changes in how negotiations are conducted with the companies concerned and in how contract prices are determined.

In Spain, the requirement for cost and price auditing arose with the country's participation in international weapons programmes. In this field of international cooperation, it was necessary to comply with the obligations to Spain's Nato partners, and to learn from their greater experience in the economic control of defence equipment procurement (Aguado, López and Vera, 2010). Thus, the Spanish audit body known as the Cost Evaluation Group (GEC, Spanish initials) was created in 1988, in accordance with the provisions of Section 5 of the Memorandum of Understanding on the programme to define collaboration, development, production and logistic support for the Eurofighter 2000 weapon system.

Since its implementation, cost and price auditing has contributed positively to the pricing of non-competitive defence contracts, by alleviating the effects of the absence of market instruments in such contracts. Furthermore, this type of contract is awarded under a negotiated procedure, and so the economic and technical information provided by cost and price auditing is of fundamental importance to the procurement authority in negotiating the contract.

In addition, there are other reasons, in our view, that justify performing an analysis of cost and price auditing in Spain, namely: 1) the initial adaptation of contract auditing to the Spanish context, and the evolution of this practice since its implementation in Spain, makes it necessary to have a good understanding of the current process; 2) the increased volume of cost and price analyses required of the GEC in recent years is generating expectations about its performance that require us to identify and characterise its various modes of operation and the coordination achieved among them.

On the basis of past experience, with cost and price auditing having been implemented in Spain over several decades, the following objectives for this paper are established: to analyse the entire cost and price auditing process, highlighting its characteristics and the degree to which its stated goals are achieved; to analyse the audit procedures most commonly used today by Minisdef audit bodies; and finally, to analyse the results obtained, in terms of financial savings.

\section{Background}

The study of cost and price auditing in defence contracts forms part of the broader context of the auditing of public procurement of goods and services.

At the international level, the USA has the most experience in the field of cost and price analysis and in the auditing of public contracts (Canales, 2000), especially in the procurement of defence equipment. Indeed, little research has been published regarding contract auditing, except in the USA, where this debate arose several decades ago, and where studies have been made of areas such as government contracts (Bedingfield and Rose, 1985), cost and price analysis (Garret, 2008; Murphy, 2009; Oyer, 2005), contract profits (Soct, 2008), the Cost Accounting Standards Board (Abel, 2006) and the Defense Contract Audit Agency (Ford, 2006; 
Horan, 2009). In Europe, the issue has tended to be addressed in an incidental manner, within more general studies on procurement (government contracts). In addition, the information restrictions often imposed by defence departments regarding the contracts entered into with companies in the sector present major obstacles to the performance of specific studies by any authors outside the department of defence on the implementation of cost and price auditing and the results obtained from it. For this reason, very few external researchers have examined the field of defence contract auditing.

The first observation that arises on considering the question of cost and price auditing is the scant body of previous research in this field in Spain, other than that performed by MINISDEF itself. Accordingly, in this paper we take the opportunity to shed greater light on the value of cost and price auditing for managers of public resources.

Research conducted in Spain includes the studies by Aguado, López and Vera (2010, 2013, 2014), who analysed the role of cost and price auditing as an instrument for rationalising public defence spending. In addition, comparative studies with other European countries have been conducted, and the notable influence of US contract audit methodology on the Spanish system has been highlighted. Arias, Pastor and Huerta (2009) considered the contribution of cost and price auditing to contract pricing in situations when market forces are absent. Finally, Gómez (2006) sought to define the characteristics of cost and price auditing in contrast to other approaches adopted in the public sector.

Cost and price auditing is a form of performance audit; in other words, it is an audit of economy and efficiency, intended to provide useful information so that contracting authorities can acquire goods and services at the best (or at least at acceptable and reasonable) prices (Aguado, López and Vera, 2010).

In the development of cost and price auditing in Spain, three significant regulatory provisions have been adopted, giving rise to the present model:

First, Instruction No. 300/00001/1988, of 12 December 1988, issued by the Secretary of State for Defence, on the assessment of costs in companies that supply the Ministry of Defence, for which purpose the GEC was created.

In Spain, the GEC is the agency responsible for performing cost and price auditing. It is part of the Secretariat of State for Defence, within the Directorate General for Economic Affairs (Digeneco) of Minisdef, which is the governing body responsible for the preparation, planning and development of the department's economic and financial policy and for the supervision and management of policy implementation. The GEC is incorporated within the Sub-Directorate General for Procurement and performs cost and price analyses on companies that supply goods and/or services or are otherwise involved in defence programmes. Although GEC staff belong to Minisdef, the audit authority does not form part of the organic or functional structure of the Minisdef procurement agencies. In other words, the GEC carries out its work autonomously, and independently of the users of its reports. The GEC issues non-binding technical reports on contract costs, and provides them exclusively to Minisdef procurement agencies, not to any other ministry. The purpose of these reports is to provide a technical opinion or judgment, intended to be of use for Minisdef decision-making bodies. 
The second regulatory provision is Ministerial Order 238/1998, of 15 October, on the presentation and auditing of tenders and on the criteria to be used in calculating the costs of contracts for manufacturing, consulting and assistance, and regarding Minisdef services to be awarded by the negotiated procedure. This Ministerial Order is the first to regulate MINISDEF's power to exercise cost and price auditing, its scope and the rules governing the structure and composition of defence contract costs.

In general, cost and price auditing is applied to contracts for manufacturing, consulting and assistance and for services to be awarded by negotiated procedure, with no public call for tenders, with a budget equal to or greater than $€ 901,518.16$.

To ensure the effective exercise of cost and price auditing and for greater transparency in the actions of the contracting authority, firms operating in this sector are subject to a specific clause in defence department procurement contracts by which the contracting authority reserves the right to assess contract costs by auditing and/or analysis. To facilitate this task and to improve efficacy, three main obligations will be stipulated in such contracts: the submission of information on contract costs and prices in a specific format, according to standard models established by the defence departments of each country; collaboration in the process of cost and price assessment; and the provision of all documentation required by the administrative authorities responsible for this assessment (Aguado, López and Vera, 2013).

Therefore, to ensure the proper submission of tenders and to enable Minisdef to effectively apply cost and price analysis techniques to defence procurement, Minisdef has published rules, termed Nodecos, to regulate the structure and composition of contract costs.

Finally, Instruction No. 128/2007, of 16 October, established the procedure for the provision of cost and price analysis services in the area addressed by Minisdef. These rules classify and regulate the different forms of cost and price auditing carried out by the GEC, some of which are analysed in the following section.

These actions are performed in the framework of current policies to improve procedures for the scheduling and control of Minisdef spending. In this respect, the GEC is an appropriate body for analysing costs and prices, for monitoring the efficacy of the decisions taken and for taking these analyses into account at the start of the budgeting process (Infodefensa, 2010; Méndez, 2010).

\section{Cost and price auditing}

In general, cost and price auditing consists in reviewing the information contained in the documents submitted by firms with respect to their pricing, referring either to estimated costs and proposed profit, or to the costs incurred in executing the contract, in order to issue a professional opinion as to whether this information complies with the rules or agreements applicable. 


\subsection{Types of cost and price auditing}

Cost and price auditing, as noted above, is a specific class of auditing. It comprises various types, each of which has a specific purpose and is subject to specific rules.

The different types of cost and price auditing are classified in Instruction 128/2007, of 16 October, issued by the Secretary of State for Defence (Sedef), establishing the procedure for the provision of cost and price analysis services in the area of competence of Minisdef. Three types of cost and price audit were created, according to their different objectives: bid audit, unit cost and price audit and incurred-cost audit.

\subsubsection{Bid auditing}

This type of audit is conceived as an ex-ante control (see chart 1) and forms part of the initial procedure to determine prices within negotiated procedures or to reach pricing agreements with the firms concerned.

Chart 1

\section{Bid auditing}

\begin{tabular}{|c|c|}
\hline Concept & Purpose \\
\hline $\begin{array}{l}\text { Review of prices proposed by the company in a bid submitted } \\
\text { to the contracting authorities, once the negotiated procedure } \\
\text { for awarding the contract has started, to ensure such prices are } \\
\text { appropriate to the market, or that they represent the value of }\end{array}$ & $\begin{array}{l}\text { a) When the GEC establishes that the prices proposed by a } \\
\text { company in its bid are appropriate, no further negotiations } \\
\text { are necessary, and the contracting authority can accept these } \\
\text { prices. }\end{array}$ \\
\hline $\begin{array}{l}\text { the goods/services to be provided, by properly including the } \\
\text { costs, as calculated under the Contract Costs Rules (Nodecos, } \\
\text { Spanish initials) together with a profit proportional to the risks } \\
\text { that will be undertaken by the contractor. }\end{array}$ & $\begin{array}{l}\text { b) When it is necessary to negotiate the fixed, or maximum } \\
\text { price of the contract, or the prices applicable to it, with the } \\
\text { firm awarded the contract, due to uncertainty about the ap- } \\
\text { propriateness of the prices proposed, the GEC provides the } \\
\text { necessary information base for these negotiations, together } \\
\text { with an alternative means of calculating the price, i.e., the } \\
\text { objective determination, measurement and assessment of } \\
\text { the content of the contract and of the risks involved. }\end{array}$ \\
\hline
\end{tabular}

Source: The authors, based on Secretary of State for Defence (Sedef), Instruction 127/2007.

In terms of the stage of the procedure at which it is conducted (i.e., during negotiation of the contract and before its award) and of the goals pursued, bid auditing in Spain bears many similarities to the bid auditing carried out in the USA and to the ex-ante controls applied in France and Norway.

As in France, bid auditing is the approach preferred by authorities responsible for supervising defence contracts, as an alternative to the auditing of costs incurred.

The current predominance of this type of auditing is due to the need of contracting authorities (and their own interest in the matter) to achieve greater transparency in negotia- 
ted procurement procedures. Another relevant factor is the search for potential cost savings or other adjustments during negotiations with the contractor before finalising the contract (Minisdef, 2008).

Bid auditing requires two types of complementary activity to be performed: the creation of an audit report (the document setting out the auditor's professional opinion on the matters under review); and the provision of advice and support to contracting authorities (with respect to cost analysis) to establish appropriate strategies for negotiations with the contractor (Aguado, López and Vera, 2010).

To achieve its goals, the GEC must obtain sufficient and appropriate evidence by conducting and evaluating the tests deemed necessary for a reasonable judgment to be reached and for an opinion to be expressed on the costs underlying the formulation of a bid to execute a given contract, with regard to the following questions: (a) the reasonable nature, quantity and quality of the inputs charged to the contract; (b) the assignability of the costs to the Minisdef contract; (c) compliance with the costing rules and criteria established by Minisdef and with generally-accepted management accounting principles; (d) compliance by the costs charged to the contract with the limitations and/or exclusions set out in the contract and with applicable legislation, and in particular with the provisions of the Contract Cost Rules (Nodecos, Spanish initials) laid down by Minisdef.

\subsubsection{Unit cost and price auditing}

This type of audit resembles the ex-ante cost and price reviews applied to production inputs in the USA (Aguado, López and Vera, 2014). The term 'unit costs and prices' (see chart 2) refers to the rates, ratios or coefficients commonly used by companies to determine their direct and indirect costs in a standard way. These coefficients usually correspond to the units of time, output or other relevant aspects used to measure the benefit derived from, or the consumption of, the resources required for the productive activity.

\section{Chart 2}

\section{Unit cost and price auditing}

\begin{tabular}{|c|c|}
\hline Concept & Purpose \\
\hline $\begin{array}{l}\text { Review of unit prices and costs (rates, ratios or coefficients) } \\
\text { proposed by the company, to ensure they are appropriate to the } \\
\text { market, or that represent the real value of the units of time (or of } \\
\text { another nature) used to measure the consumption of productive } \\
\text { resources, calculated in accordance with Nodecos criteria. }\end{array}$ & $\begin{array}{l}\text { a) To facilitate agreement between the Directorate-General } \\
\text { for Economic Affairs and the company regarding the unit } \\
\text { prices and costs to be used in bids and, when appropriate, } \\
\text { in calculating the costs incurred in implementing contracts } \\
\text { with Minisdef contracting authorities. }\end{array}$ \\
\hline & $\begin{array}{l}\text { b) To facilitate the calculations to be performed by Minisdef } \\
\text { departments with respect to budgeting for the costs of } \\
\text { defence contracts. }\end{array}$ \\
\hline
\end{tabular}

Source: The authors, based on Sedef Instruction 127/2007. 
Unit costs and prices for defence contracts are calculated for each organisational area or line of activity within the firm. This calculation requires the firm to comply with the Nodecos criteria, to ensure consistent application.

The Minisdef Directorate-General for Economic Affairs (Digeneco, Spanish initials), via the GEC and exclusively with respect to Minisdef activities and interests, promotes this kind of review of the companies that regularly participate in negotiated procedures for the award of high-value defence contracts, seeking to achieve two complementary goals: (a) that the unit costs and prices agreed with the firms concerned should apply to all Minisdef contracts to determine the overall price; (b) that the firms should address Minisdef as a single client.

\subsubsection{Incurred-cost auditing}

Incurred-cost auditing (see chart 3) is performed once the contract has been executed. Its main purpose is to revise the cost records included in the audit submitted by the contractor, and then to express an opinion as to whether these records faithfully reflect the costs actually incurred in completing the contract. The audit will also rule on the reasonableness of the risk estimate underlying the contractor's profit calculation. For these purposes, the "true picture of the cost statements" is defined as the real valuation of the consumption of production factors necessary to perform the contract, and "cost statement or audit basis" is the document presented by the contractor setting out the full cost attributed to the object of the contract.

Chart 3

Incurred-cost auditing

\begin{tabular}{|l|l|}
\hline \multicolumn{1}{|c|}{ Concept } & Purpose \\
\hline $\begin{array}{l}\text { Review of the costs incurred by a contractor or a) In maximum-price contracts: to determine the definitive price of the } \\
\text { subcontractor in the performance of the contract, } \\
\text { to confirm that the cost calculation is in accordance } \\
\text { with NODECOS criteria. }\end{array}$ & $\begin{array}{l}\text { contract, after confirming that the costs declared by the contractor or } \\
\text { are calculated in accordance with the rules applicable to the contract. }\end{array}$ \\
$\begin{array}{l}\text { b) In general: to obtain reliable information about the costs involved in the } \\
\text { performance of the Minisdef contract, and about the profit margins actually } \\
\text { obtained by the suppliers or those participating in the defence programme } \\
\text { in question. }\end{array}$
\end{tabular}

Source: The authors, based on Sedef Instruction 127/2007.

A comparison of incurred-cost auditing with other practices and with international experience shows that, taking into account the stage of the procedure at which it takes place, its object and purpose, it bears a strong resemblance to the French approach to price control and also to the contract auditing methods used in Norway. However, with respect to the contract auditing carried out in the USA and the ex-post costing practiced in the UK, there are important differences as regards the economic consequences of this procedure (Aguado, López and Vera, 2013). 
This type of audit is of the a posteriori type, in which historical data on the actual costs incurred in the Minisdef contract are analysed. Initially, most of the audit work performed by the GEC was of this type, spurred by users' need, during the early years of contract auditing, to determine the degree of agreement between the price established in the contract negotiation (under the fixed contract price formula) and the real costs. The development of this type of auditing has also been influenced by the cooperative attitudes presented by contractors, in view of the fact that such audits have not provoked demands for them to make subsequent economic adjustments.

Moreover, although in theory the incurred-cost audit report should examine the reasonableness of the estimated risks incorporated in the contractor's profit margin, in fact, the audit reports reviewed do not make any reference in this respect.

\subsection{The model of cost and price auditing}

The purpose of the audit is to assist the authorities responsible for Minisdef procurement, providing information of an economic-financial nature relating to the operations involved in a particular contract. Contract, or cost and price auditing requires judgments to be made about accounting, economic and financial issues, and these judgments will subsequently constitute the basis for all negotiations regarding prices and costs.

Following Aguado, López and Vera (2010), the methodological process established by the GEC to conduct cost and price auditing (see Figure 1) is divided into six phases:

Figure 1

Cost and price audit process

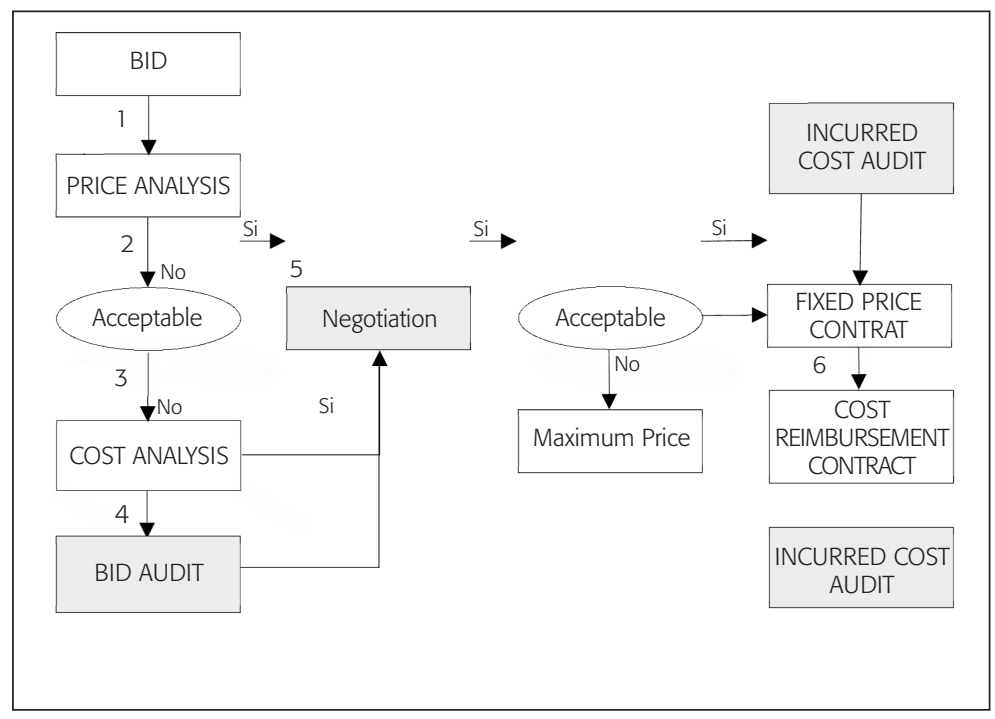

Source: Aguado, López and Vera (2010). 
The actions preparatory to the contract are those that are normally required by the contracting rules applicable. Thus, the document containing the relevant administrative clauses will stipulate, on the one hand, the contractor's obligation to present the bid in a specific, detailed form, following a model established by Minisdef, to enable the effective performance of the audit and to reflect the costs incurred, and, on the other hand, the contractor's obligation to maintain the accounting documents for the period specified in the corresponding tax regulations (five years). This document also specifies Minisdef's right to audit both the contract bid and the costs actually incurred in the performance of the contract, although the latter audit may not be used to demand subsequent economic adjustments. The contracting authority, if the case in question is not one in which the contract value is indeterminate, will assess the economic value of the object of the contract, and this valuation will constitute the budget limit that will be applied to it.

\section{1) Presentation of bids}

Companies that are willing and eligible to participate in the contract bidding process must present their bids including a detailed description of the technical approach to be taken to the task in question, together with a breakdown of the price proposed, in accordance with their standard practice for determining costs and profit margins, and always subject to the Nodecos format, i.e., without including any cost that is declared inadmissible by these rules.

\section{2) Price analysis}

When the object of the contract constitutes goods or services about which the contracting authority has prior experience and good understanding, having participated in a similar contract previously, the bid price will be analysed by the procurement agency and, if it is considered acceptable, in relation to existing market prices, negotiations will be initiated with the bidder in order to overcome any technical and economic differences identified in the corresponding analysis. The price resulting from these negotiations, plus the value added tax applicable, will constitute the definitive price, either total or per unit, to be paid to the contractor for performance of the contract, in accordance with the payment schedule agreed.

\section{3) Cost analysis}

The cost analysis methodology applied by the GEC is based on the Contract Pricing Reference Guides published by the US Department of Defence. The firm's cost statements are reviewed by coordinated groups, each with specific objectives and procedures, in accordance with this classification: a) Direct costs: Materials; Direct labour; Other direct costs; 
b) Indirect costs: General supply costs; General production costs; General administration costs; and Financial costs. The submission of information on contract costs and prices is performed as shown in table 1.

Table 1

Breakdown of tender price and costs incurred in executing the contract in Spain

\begin{tabular}{|clcc|}
\hline Item & Concept & $\begin{array}{c}\text { Formula for } \\
\text { price tendered }\end{array}$ & $\begin{array}{c}\text { Formula for } \\
\text { costs incurred }\end{array}$ \\
A & Direct costs & $=A+B$ & \\
B & Indirect costs & $=$ A+B \\
C & Total production cost & $=\mathrm{C}+\mathrm{D}$ \\
D & Profit & \\
E & Price of the products and/or services to be delivered & \\
F & Other costs accepted in the contract, non-assignable to the products or services & \\
G & Tax liability & $=\mathrm{E}+\mathrm{F}+\mathrm{C}$ & \\
H & Price of the contract & & \\
I & Total costs incurred in the execution of the contract & \\
\hline
\end{tabular}

Source: The authors, based on Instruction 128/2007.

If the price analysis shows that there is insufficient competition or that, even if a competitive market exists, the bids presented appear to be excessive and out of line with market prices, then a cost and price analysis will be performed, in order to determine the degree to which the bid and the cost data on which it is based reflect the true costs of contract performance, assuming a reasonable level of economy and efficiency.

Such an analysis will also be conducted if there is no prior experience of this kind of contract, or if the data are insufficient. In this case, the contracting authority must take into account the existence of considerable uncertainty, both for itself and for the contractor, and consequently, greater precautions must be taken. Under these circumstances, the contract price will be determined according to the total costs plus a profit margin proportional to the risks associated with the object of the contract.

\section{4) Bid auditing}

If the results of the cost and price analysis are not satisfactory, the contractor's bid will be audited by Minisdef. If all uncertainties are resolved satisfactorily, and the corresponding report to this effect issued, the bid will be declared sufficient and the negotiation process initiated. 


\section{5) Negotiation}

Any deficiencies arising from non-competition and/or a lack of transparency in the defence market with respect to contract pricing in negotiated procurement should be overcome by negotiations with the firms concerned.

With the information obtained from the cost and price analysis or from the bid audit, the contracting authority will then proceed to the negotiation phase with the firms admitted to this process. This phase will be used to address doubts and questions that may be raised by the contractor about the data contained in the offer. In these sessions, both parties will be supported by specialist advisors and will seek to reach an agreement on the contract price and terms, not only economic ones but also those of a technical and/or administrative nature. If these negotiations result in an agreement being reached between the parties, it must be documented and the definitive contract price established.

Once negotiations have resolved all the uncertainties observed at the outset, the pricing agreement reached with the contractor will determine the exact amount of the contract price at the time of the award, or, if uncertainties persist, the maximum amount payable and the method to be used to calculate the exact amount at a later time (which in no case may exceed the said maximum). This calculation method will take into account variables whose value will be ascertained at a time subsequent to the contract award and prior to the formal act of receiving the object of the contract. These variables may relate, for example, to the costs incurred by the contractor, to elements relevant to the assessment of these costs, to the profit margin

to be perceived, or to incentives offered to the contractor to obtain economies with respect to a cost target.

After having agreed the work to be done and the unit costs and profits to be assigned, as stipulated in the negotiation, these factors plus the value added tax will constitute the definitive contract price.

In summary, the amount payable is calculated from the admissible costs actually incurred, assessed by analysis or audit and approved by the contracting authority, plus the profits agreed to and the corresponding value added tax.

\section{6) Incurred-cost audit}

When prices are determined provisionally, a maximum price for the contract to be performed is usually established, and the contract takes the form of cost reimbursement, or cost plus contract. In this type of contract, Minisdef pays the costs incurred plus a profit incentive, determined by comparing the real costs to cost targets and adjusting the profit within negotiated maximum and minimum levels. In this case, the incurred-cost audit does influence the calculation of the costs to be reimbursed to the contractor, and thus the price payable. 


\section{Results obtained from cost and price auditing}

To correctly interpret the results shown in this section, it is first necessary to relate them to the characteristics of the different audit procedures that produce savings (bid auditing and incurred-cost auditing) and to the stage of the cost and price auditing process performed. The greater savings achieved with bid auditing (as described below) are due not only to the greater number and financial value of the contracts audited, but also to the fact that this auditing is carried out during the pre-negotiation phase, which enables a prior control of the prices considered in order to guide contracting authorities in reviewing and obtaining the final pricing of the contract. On the other hand, incurred-cost auditing is performed in the phase subsequent to the negotiation, and lower savings are achieved because if the contract price has already been determined in the negotiation, any later audit will not produce adjustments to the prices previously agreed with the company. Only in the case of contracts with provisional pricing or with cost reimbursement (the least common for$\mathrm{ms}$ ) will incurred-cost auditing have a direct influence on pricing. In short, a priori audits, carried out before negotiation, are more effective than those which take place after the negotiation phase.

To assess the results obtained by the GEC in the course of its activities, we present the cost adjustments achieved during the period 2004-2013 (the latest data published by Minisdef).

Our study of the results obtained by the GEC enabled us to fulfil two of the research goals established at the outset: to analyse the activity of the GEC over an extended period, by type of work done, in order to highlight the audit procedures that are most commonly employed and/or most effective; and to analyse the savings achieved by the GEC during this extended period for each type of study performed. In short, the results obtained highlight the efficiency provided by cost and price auditing applied to procurement and the implementation of public expenditure in Spain.

However, it should be made clear that the data presented are not entirely comparable throughout the time period analysed. From 2004 until the publication of Instruction 128/2007, of 16 October, by Sedef, the data are presented in aggregate form. From 2008 until the present, following the creation of a GEC coordination unit in 2011, the main data for GEC activity are homogeneous and comparable. Finally, it should be noted that this analysis is more detailed for the most recent data available (referring to activities in 2012 and 2013).

Table 2 shows the results obtained by the Minisdef contracting authorities from the use of the various types of cost and price auditing, in accordance with Sedef Instruction $128 / 2007$. 
Table 2

Results obtained by the GEC during the study period (2004-2007)

(Sums in millions of euros)

\begin{tabular}{|c|c|c|c|c|c|}
\hline FUNCTION & TYPE OF TASK & $\begin{array}{l}\text { № OF } \\
\text { TASKS }\end{array}$ & $\begin{array}{l}\text { BASE } \\
(\mathrm{M} €)\end{array}$ & $\begin{array}{l}\text { ADJUSTMENTS } \\
\qquad(\mathrm{M} €)\end{array}$ & $\begin{array}{c}\% \\
\text { SAVING }\end{array}$ \\
\hline \multirow{7}{*}{$\begin{array}{l}\text { Analysis of } \\
\text { companies' costs } \\
\text { and prices }\end{array}$} & $\begin{array}{l}\text { Estimation of } \\
\text { costs and prices }\end{array}$ & 2 & 0.00 & 0.00 & \\
\hline & $\begin{array}{l}\text { Audit of bids and } \\
\text { quotes }\end{array}$ & 24 & $2,939.71$ & 243.73 & \multirow[t]{2}{*}{8.29} \\
\hline & Audit of unit costs & 24 & 0.00 & 0.00 & \\
\hline & Audit of costs incurred & 23 & 569.54 & 23.86 & 4.19 \\
\hline & $\begin{array}{l}\text { Cost/price } \\
\text { analysis for } \\
\text { contract execution }\end{array}$ & 27 & 0.00 & 0.00 & \\
\hline & TOTAL & 100 & $3,509.25$ & 267.59 & 7.63 \\
\hline & Analysis of the Cost of public services & 3 & 0.00 & 0.00 & \\
\hline \multirow{2}{*}{$\begin{array}{l}\text { Analysis of costs in the } \\
\text { Minisdef } \\
\text { sector }\end{array}$} & $\begin{array}{l}\text { Analysis of the } \\
\text { cost of activities }\end{array}$ & 1 & 0.00 & 0.00 & \\
\hline & TOTAL & 4 & 0.00 & 0.00 & \\
\hline \multicolumn{2}{|c|}{ Reports prior to orders to proceed } & 496 & 40.00 & 2.44 & 6.10 \\
\hline \multicolumn{2}{|l|}{ TOTAL (2004-07) } & 600 & $3,549.25$ & 270.03 & 7.61 \\
\hline
\end{tabular}

Source: Minisdef (2008).

From the data shown in table 2, relating to 2004-2007, three significant aspects are apparent: first, the total Minisdef budget saving achieved was 270 million euros; this represents $7.61 \%$ of the total sum ( $€ 3.549$ billion) reviewed by the GEC. Second, the greatest savings, in both absolute and relative terms, resulted from bid audits, in which a saving of 8.3\% ( $€ 244$ million) was obtained with respect to the original price quoted by the companies. Third, GEC has increasingly participated in the procedure for approving orders originating from Sedef, achieving prior savings of $6.10 \%$ of the sum presented for revision.

The above-mentioned adjustments, concerning both bid audits and incurred cost audits, arose from the comparison made between the values recorded in the audit database (the formalised document presented by the companies involved, setting out all components of the contract price and, implicitly, the cost structure underlying the price calculation) and the costs that the GEC considers to be eligible, in accordance with the Nodecos. This comparison is used to identify queried costs, which will require adjustments to be made to the audit database. The study of these discrepancies is based on analyses of the technical reasonableness of the use of production factors and of the economic reasonableness of the estimated costs that are included in the initial audit database. The savings achieved by means of these controls are 
located primarily in the reviews of the direct labour costs, both those of the company itself and those corresponding to outsourced direct labour, and in the calculation of surcharges for indirect manufacturing costs, materials handling costs and general and administrative expenses.

Table 3 shows the cost savings results achieved by the Minisdef each year during the period 2008-2013 by the use of cost and price auditing, but without distinguishing between the different forms.

Table 3

Summary of GEC activities and savings

\begin{tabular}{|cccccc|}
\hline YEAR & \multicolumn{2}{c}{ ACTIVITY } & \multicolumn{2}{c|}{ SAVING OR VALUE GENERATED } \\
\hline & $\begin{array}{c}\text { Audits } \\
\text { completed }\end{array}$ & $\begin{array}{c}\text { Audits with } \\
\text { potential cost } \\
\text { savings }\end{array}$ & $\begin{array}{c}\text { Value of contracts } \\
\text { audited }(€ \mathrm{~m})\end{array}$ & $\begin{array}{c}\text { Savings achieved } \\
(€ \mathrm{~m})\end{array}$ & $\begin{array}{c}\text { Savings/value } \\
\text { audited }(\%)\end{array}$ \\
\hline 2008 & 23 & 15 & 141.36 & 11.45 & 8.1 \\
2009 & 36 & 18 & 445.53 & 11.93 & 2.7 \\
2010 & 36 & 18 & 289.70 & 35.25 & 12.2 \\
2011 & 37 & 19 & $1,502.69$ & 67.89 & 4.5 \\
2012 & 55 & 18 & $1,318.73$ & 83.77 & 6.4 \\
2013 & 63 & 25 & 964.24 & 39.69 & 4.1 \\
TOTAL & 250 & 113 & $4,662.25$ & 249.98 & \\
\hline
\end{tabular}

Source: Digeneco (2014).

The following observations can be drawn from this table: the GEC's activity, measured by the number of tasks performed, is increasing; the number of audits producing savings for the Minisdef remained stable with the exception of 2013, when an increase occurred; the financial value of the contracts audited increased greatly from 2011, and so the savings obtained from this date were also higher.

These results reveal a clear correlation between the savings obtained in absolute terms and the financial value of the contracts audited by the GEC. On the other hand, the savings obtained, measured as a percentage of the volume of resources analysed, have stabilised in recent years between $4 \%$ and $6.5 \%$.

In relation to the GEC's activities in 2013 (the most recent year for which published data are available), table 4, which reflects the data produced by Digeneco (2014), shows that 63 audits were performed in 2013, eight more than the previous year, which confirms the rising trend in its activity.

However, the annual demand for audits to be performed by GEC has increased at a much higher rate, and so if GEC maintains its current level and structure of human and material resources it will not be possible to generalise the cost and price auditing of non-competitive contracts. 
Table 4

GEC activities 2013

\begin{tabular}{|lccc|}
\hline GEC ACTIVITIES IN 2013 & 2013 & 2012 & Increase \\
\hline Audits requested & 139 & 95 & $46.32 \%$ \\
Audits completed & 63 & 55 & $14.55 \%$ \\
Coverage of demand & $45.32 \%$ & $57.89 \%$ & \\
\hline
\end{tabular}

Source: Subdirección General de Contratación del Minisdef (2014).

The distribution of the 63 audits concluded by GEC in 2013, by type of activity, is shown in table 5 . Here, it can be seen that the volume of audit work has remained constant, while the work to provide support to decision making processes has increased significantly, by $58.8 \%$, due to the increased involvement of GEC in studies to determine the feasibility of future procurement programmes, especially in the field of armaments and defence equipment.

Table 5

GEC audits completed in 2013

\begin{tabular}{|lcccc|}
\hline \multicolumn{1}{|c}{ GEC ACTIVITIES IN 2013 } & & 2013 & 2012 & $\begin{array}{c}\text { Increase } \\
2013-2012\end{array}$ \\
\hline Audits in support of decision making & $(1)$ & 27 & 17 & $58.82 \%$ \\
Audits in support of contractual processes & $(2)$ & 36 & 38 & $-5.26 \%$ \\
\hline
\end{tabular}

NOTE 1: Cost and price estimation. Advising management and programme administrators.

NOTE 2: Audits for negotiations and determination of contract prices.

Source: Sub-Directorate General for Procurement (2014).

In 2013, GEC audited the incurred costs declared for twelve contracts, and also audited thirteen bids. The total value of the contracts of this type that were audited was $€ 964,238,619.68$.

As a result of this audit activity (of bids and of costs incurred), a saving of $€ 39,692,038.62$ was made, according to GEC data for 2013, as detailed in table 6 (Sub-Directorate General for Procurement, Ministry of Defence, 2014).

Table 6

GEC audits completed in 2013

\begin{tabular}{|lcccc|}
\hline \multicolumn{1}{|c}{ Type of audit } & $\begin{array}{c}\text { Number of audits } \\
\text { performed }\end{array}$ & $\begin{array}{c}\text { Total contract value } \\
\text { audited }(€)\end{array}$ & Savings achieved $(€)$ & $\%$ Saved \\
\hline INCURRED COSTS AUDIT & 12 & $523,713,604.68$ & $9,730,656.62$ & $1.9 \%$ \\
BID AUDIT & 13 & $440,525,015.00$ & $29,961,382.00$ & $6.8 \%$ \\
TOTAL & 25 & $964,238,619.68$ & $39,692,038.62$ & $4.1 \%$ \\
\hline
\end{tabular}

Source: Digeneco (2014). 
The total amount audited by GEC in 2013 was substantially lower than in 2012, which is attributed to the specific conjuncture of budget restrictions applied to Minisdef investment in 2013.

Savings of nearly 40 million euros were achieved, representing $4 \%$ of the amount reviewed or analysed. These figures are lower than those recorded in previous years (see table 3 , which shows the evolution of audit activity and the savings achieved by GEC). According to Digeneco (2014), this outcome is due to the following reasons:

a) The current structure of GEC is evolving toward a model similar to that established in other countries in our region, according to which audit activity is distributed evenly between cost auditing and audits in support of contractual processes. This model is expected to enhance decision-making and the management of resources.

b) Although the total number of audits performed has increased, those with the potential to produce cost savings have declined and correspond to assignments of lower values than in previous years. In this respect, we note that savings are usually greater when the audit to be performed concerns programmes that are more complex and costly.

c) Companies have become accustomed to implementing MINISDEF criteria. Thus, errors or areas of non-compliance are approaching statistical normality, and the saving obtained by the audit, in relation to the total contract value, will thus tend to stabilise at figures below $5 \%$.

Finally, these results are supplemented by a cost-benefit analysis (see table 7), in which the net cost of the GEC, according to the analytical accounting service of Minisdef for 2012 and $2013(€ 3,573,000)$, is contrasted with the savings reflected in the above tables.

Table 7

Cost-benefit indicators 2012 and 2013

\begin{tabular}{|lrl|}
\hline Net cost of the GEC (cost - savings achieved) & 2012 & \\
$€$ saved by the GEC per $€$ of GEC cost & $-80.1 \quad €$ million \\
& $23.4 \quad €$ saved per $€$ cost \\
Net cost of the GEC (cost - savings achieved) & 2013 & \\
$€$ saved by the GEC per $€$ of GEC cost & $-36.1 \quad €$ million \\
\hline
\end{tabular}

Source: Digeneco (2014).

This comparison of GEC costs and savings shows that for every euro of GEC cost, savings of $€ 23.4$ and $€ 11.1$ were obtained in 2012 and 2013, respectively. 


\section{Conclusions}

To understand the results obtained from our empirical study, and to properly assess the findings presented, the limitations of this study should be taken into account. First, the only source of data is the Minisdef, which has traditionally classified information on such contracts as an issue of restricted disclosure, because it affects areas of national defence and involves information that is often considered confidential by the companies involved. Second, changes in how the data on GEC activities are presented during the study period may distort the data comparison performed. Nevertheless, in the opinion of the authors, the study does make an important contribution to our understanding of the issues addressed, by demonstrating the usefulness and efficiency of cost and price auditing by the Spanish Ministry of Defence.

The US model is the main source of inspiration for the methodology applied in cost and price auditing in Spain, where American standards on contract auditing have been adapted to the characteristics of this country and to its legislation.

As concerns the specific work of analysing the costs and prices of non-competitive contracts made by the GEC, on the basis of the information provided by the companies concerned, it is apparent that although all costs are analysed comprehensively by the audit body, the review of profit margins is usually omitted. This is an aspect that presents a challenge to the GEC and one in which improvements should be made.

Regarding the various forms of cost and price auditing, a trend can be observed within the GEC in which more emphasis is being placed on tasks related to resource planning and budgeting (decision-making support), to the detriment of work in support of contractual processes. In turn, within the latter tasks, ex-ante controls (bid audits and unit cost and price audits) are becoming increasingly common, in view of their ability to generate monetary savings before contract prices are determined, rather than ex-post controls (incurred-cost audits), which are more time-and-resource consuming in relation to the monetary savings obtained.

Despite the limited resources available to the GEC to carry out its responsibilities, cost and price auditing strengthens the negotiating position of Minisdef with companies, by providing contracting authorities with tools for evaluation and control, thus enabling them to establish fair and reasonable prices in non-competitive contracts. In short, cost and price auditing contributes to the more efficient application of public resources, especially in cases in which price assessment and negotiation must be based on the cost data provided by the firms concerned, due to the lack of market references.

\section{References}

ABEL, Rein. The rise and fall of the Cost Accounting Standards Board. The Journal of Government Financial Management, v. 55, n. 3, p. 46-51, 2006.

AGUADO, José; LÓPEZ, Antonio; VERA, Simón. Auditing defence procurement contracts in the European context: an inter-country analysis. International Review of Administrative Sciences, v. 79, n. 4, p. 659-680, 2013. 
AGUADO, José; LÓPEZ, Antonio; VERA, Simón. Auditing procurement contracts for defense materiel in Spain: in the footsteps of the U.S. model. Journal of Public Procurement, v. 14, n. 2, p. 252-282, 2014.

AGUADO, José; LÓPEZ, Antonio; VERA, Simón. Cost and price auditing as a tool for public expenditure rationalization of defense in Spain. Spanish Accounting Review, v. 13, n. 2, p. 211-238, 2010.

ÁLVAREZ, Isabel; FONFRÍA, Antonio. Estructura e innovación en la industria de defensa española. Revista Economistas, v. 85, p. 102-121, 2000.

ARIAS, Javier F.; PASTOR, Javier; HUERTA, Justo A. La determinación del precio en situaciones de carencia de referencias de mercado y escasa concurrencia. Contratación administrativa práctica. Revista de la Contratación Administrativa y de los Contratistas, v. 89, p. 37-69, 2009.

BEDINGFIELD, James; ROSE, Louis. Government contract accounting. 2nd edition. Washington: A Federal Publications Government Contract Text, 1985.

BAREA, José; GÓMEZ, Antonio. El problema de la eficiencia del sector público en España: especial consideración de la sanidad. Madrid: Instituto de Estudios Económicos, 1994.

CANALES, Álvaro. El control de eficiencia sobre el precio en la contratación pública: el incidente de diálogo competitivo. Madrid: Centro de Publicaciones de la Secretaria General Técnica, Ministerio de Defensa, 2000.

DIRECCIÓN GENERAL DE ASUNTOS ECONÓMICOS DEL MINISDEF. Actividad económico presupuestaria contable y contractual del Ministerio de Defensa en 2013. Madrid: 2014. Available in: <http://intradef.mdef.es/portal/intradef/Ministerio_de_Defensa/Principal/Organo_Central/Asuntos_economicos/Asuntos_economicos/Asuntos_economicos?_nfls=false $>$. Access on: Jan. 8, 2015. FORD, John N. DCAA's audit authority. Business Credit, v. 108, n. 5, p. 46-48, 2006.

GARRETT, Gregory A. Cost estimating and contract pricing. Tools, techniques and best practices. Chicago: Wolters Kluwer, 2008

GÓMEZ, Juan C. Marco conceptual de la auditoria de costes y precios. Auditoría Pública, v. 36, p. 35-49, 2006.

HORAN, Jack. Reforms to the DCCA: the potential effect on contract management. Contract Management Journal, v. 49, n. 12, p. 92-95, 2009.

INFODEFENSA. Defensa abordará en 2010 una importante reorganización del sistema de contratación. Madrid: 2010. Available in: <http://infodefensa.com/esp/noticias/noticias_ref.asp?search> . Access on: Feb. 8, 2015.

MCGUIRE, Martin C. Economics of defense in a globalized world. In: SANDLER, Tood; HARTLEY, Keith (Ed.). Handbook of defense economics. 2nd edition. Amsterdam: Elsevier, 2007. v. 2, chapter 21, p. 623-648.

MÉNDEZ, Constantino. Medidas de control del gasto de defensa ante la crisis económica. Presupuesto y Gasto Público, v. 58, p. 21-27, 2010. 
MINISTERIO DE DEFENSA. Memoria de la VIII Legislatura 2004-2008. Madrid: Secretaria General Técnica del Ministerio de Defensa, 2008.

MINISTRY OF DEFENCE Order No. 238/1998, of 15 October, on the presentation and auditing of bids, and on rules for the criteria to be used in the costing of certain contracts for supplies, consulting and assistance and other services to the Ministry of Defence, when awarded by negotiated procedure (NODECOS). Official State Gazette, Madrid, n. 258, Oct. 28, 1998.

MURPHY, Edward. Guide to contract pricing. Cost and price analysis for contractors, subcontractors and government agencies. 5. ed. Vienna, Virginia: Management Concepts, Inc, 2009.

OYER, Darrell J. Pricing and cost accounting. A handbook for government contractors. 2nd ed. Vienna, Virginia: Management Concepts, Inc, 2005.

SECRETARY OF STATE FOR DEFENCE. Instruction No. 300/00001/1988, of 12 December, about assessment of costs in companies supplying the Ministry of Defence.

SECRETARY OF STATE FOR DEFENCE. Instruction No. 128/2007, of 16 October, establishing the procedure for the provision of cost and price analysis services in the field of Minisdef. Official Defence Gazette, Madrid, n. 212, Oct. 30, 2007.

SOCT, A. Arnold. Does DoD profit policy sufficiently compensate defense contractors? IDA Research Notes, Fall, 2008. Available in: < htpps//www.ida.org/upload/research\%20notes/rn_fall2008_profit.pdf >. Access on: May 6, 2015.

SUBDIRECCIÓN GENERAL DE CONTRATACIÓN DEL MINISDEF. Grupo de Evaluación de Costes. Memoria 2013. Madrid: 2014. Available in: < http://intra.mdef.es/intradef/contenido_INET_Active/ Contenidos/Organo_Central/Asuntos_economicos/s080330/Documentos/MEMORIA\%20GEC\%20 2013_09003a9980542ec5.pdf>. Access on: Jan. 10, 2015.

José Aguado Romero is Major of the Military Audit Corps in the Spanish Ministry of Defence, and responsible for financial management, cost control and public sector auditing. Also He is Doctor of Economics and associate professor at the University of Granada. E-mail: jaguado@ugr.es.

Antonio M. López-Hernández is President of Audit Office of Andalucía (Spain). Also He is Doctor of Economics and professor at the University of Granada. E-mail: alopezh@ugr.es. 